\title{
KOMPETENSI SUPERVISI KEPALA MADRASAH
}

\section{Irfani Nabila}

MTs Nurul Iman Cibaduyut-Bandung

Jl. Cibaduyut Raya Blok TVRI 3, Bojongloa Kidul, Kota Bandung, Jawa Barat

Email: irfaninabila.in@gmail.com

\begin{abstract}
ABSTRAK
Penelitian ini bertujuan untuk mengetahui perencanaan, pelaksanaan, evaluasi dan tindak lanjut hasil program supervisi kepala madrasah di MTs Nurul Iman. Pendekatan yang digunakan dalam penelitian ini yakni kualitatif dengan metode deskriftif. Hasil penelitian Kompetensi Supervisi Kepala Madrasah di MTs Nurul Iman, yakni: 1) Perencanaan Program Supervisi Kepala Madrasah meliputi program yang direncanakan yaitu program semester ganjil dan genap dan program bulanan; dan program yang tidak direncanakan yaitu kunjungan kelas yang tidak terjadwal. 2) Pelaksanaan Program Supervisi terkait dengan kelengkapan adiminstrasi guru/ wali kelas dan kegiatan pembelajaran di kelas. 3) Evaluasi dan Tindak Lanjut Program Supervisi di MTs Nurul Iman melalui teknik diskusi dan wawancara.
\end{abstract}

Kata Kunci: Kompetensi, Supervisi, Madrasah.

\section{ABSTRACT}

This study aims to determine the planning, implementation, evaluation and follow-up of the results of the supervision program of madrasah heads in MTs Nurul Iman. The approach used in this research is qualitative with descriptive method. The result of research of Head of Madrasah Supervision Competence in MTs Nurul Iman, namely: 1) Planning of Supervision Program of Madrasah Principal covers planned program that is odd \& even semester program and monthly program; and unplanned programs that are unscheduled class visits. 2) Implementation of Supervision Program related to the completeness of teacher / homeroom teacher and classroom learning activities. 3) Evaluation and Follow-Up Supervision Program in MTs Nurul Iman through discussion and interview techniques.

Keywords: Competence, Supervision, Madrasah.

\section{PENDAHULUAN}

Peraturan Menteri Pendidikan Nasional nomor 13 tahun 2007 tentang standar kepala sekolah menegaskan bahwa dimensi kompetensi yang harus dimiliki seorang kepala sekolah adalah dimensi kompetensi kepribadian, 
dimensi kompetensi manajerial, dimensi kompetensi kewirausahaan, dimensi kompetensi supervisi, dan dimensi kompetensi sosial. Dijelaskan lebih lanjut bahwa dimensi kompetensi supervisi diantaranya meliputi kompetensi merencanakan program supervisi akademik dengan pendekatan dan teknik supervisi yang tepat, dan menindaklanjuti hasil supervisi akademik dalam rangka meningkatkan profesionalisme tenaga pendidik.

Kepala sekolah merupakan salah satu komponen pendidikan yang paling berperan dalam meningkatkan kualitas pendidikan. Keberhasilan suatu lembaga pendidikan sangat bergantung pada kepemimpinan kepala sekolah. Pelaksanaan supervisi merupakan tugas kepala sekolah untuk melakukan pengawasan terhadap guru dan pegawai sekolahnya, kegiatan ini juga mencakup penelitian, penentuan berbagai kebijakan yang diperlukan, dan pemberian jalan keluar bagi permasalahan yang dihadapi oleh seluruh pegawainya.

Berdasarkan hasil studi pendahuluan yang dilakukan penulis, diperoleh kenyataan bahwa pelaksanaan supervisi di MTs Nurul Iman pada tahun ini belum dilakukan karena banyaknya kegiatan jadi belum melakukan supervisi. Pelaksanaan supervisi tidak semua dilakukan oleh Kepala Madrasah karena ruangan dan gurunya banyak.

Karena banyaknya kegiatan dan guru nya banyak pelaksanaan supervisi oleh Kepala Madrasah hanya dilakukan dengan cara bertanya beberapa menit untuk mengecek kelengkapan perangkat administrasi dan kegiatan supervisi tidak melihat ke guru secara langsung, tetapi dilihat dari segi administrasinya dari daftar hadir, RPP, dan sebagainya. Karena seharusnya kegiatan supervisi dilakukan secara langsung dengan memantau guru-guru di kelas sehingga Kepala Madarsah mengetahui bagaimana guru tersebut mengajar, apakah sudah sesuai atau belum. Berdasarkan fenomena tersebut, menarik untuk diteliti lebih lanjut mengenai bagaimana Kompetensi Supervisi Kepala Madrasah di MTs Nurul Iman Cibaduyut-Bandung.

\section{KAJIAN TEORI}

Peraturan Menteri Pendidikan Nasional nomor 13 tahun 2007 tentang standar kepala sekolah menegaskan bahwa dimensi kompetensi yang harus dimiliki seorang kepala sekolah adalah dimensi kompetensi kepribadian, dimensi kompetensi manajerial, dimensi kompetensi kewirausahaan, dimensi kompetensi supervisi, dan dimensi kompetensi sosial. Salah satu kompetensi yang harus dimiliki kepala sekolah adalah mampu melaksanakan supervisi.

Supervisi diartikan sebagai pembinaan yang diberikan kepada seluruh staf sekolah agar mereka dapat meningkatkan kemampuannya untuk mengembangkan situasi belajar-mengajar yang lebih baik. Dengan demikian, supervisi ditujukan kepada penciptaan atau pengembangan situasi belajarmengajar yang lebih baik.

Tujuan supervisi adalah memperkembangkan situasi belajar dan mengajar yang lebih baik. Usaha perbaikan belajar dan mengajar ditujukan kepada pencapaian tujuan akhir dari pendidikan yaitu pembentukan pribadi anak secara maksimal (Hendiyat Soetopo dan Wasty Soemanto, 1988, h. 40). Fungsi utamasupervisi adalah sebagai bimbingan. 
Seorang pimpinan pendidikan yang berfungsi sebagai supervisor dalam melaksanakan tugasnya hendaknya bertumpu pada prinsip-prinsip supervisi:

1. Ilmiah, yang mencakup unsur-unsur:

a. Sistematika, artinya dilaksanakan secara teratur, berencana dan kontinyu.

b. Obyektif artinya data yang didapat pada observasi yang nyata bukan tafsiran pribadi.

c. Menggunakan alat (instrumen) yang dapat memberi informasi sebagai umpan balik untuk mengadakan penilaian terhadap proses belajar mengajar.

2. Demokratis, yaitu menjunjung tinggi asas musyawarah, memiliki jiwa kekeluargaan yang kuat serta sanggup menerima pendapat orang lain.

3. Kooperatif, seluruh staf dapat bekerja bersama, mengembangkan usaha bersama dalam menciptakan situasi belajar mengajar yang lebih baik.

4. Konstruktif, dan kreatif yaitu membina inisiatif guru serta mendorongnya untuk aktif menciptakan suasana dimana tiap orang merasa aman dan dapat menggunakan potensi-potensinya (Hendiyat Soetopo dan Wasty Soemanto, 1988, h. 40-41).

\section{Perencanaan Supervisi}

Salah satu fungsi utama dan pertama yang menjadi tanggung jawab kepala sekolah adalah membuat atau menyusun perencanaan. Perencanaan merupakan salah satu syarat mutlak bagi setiap organisasi atau lembaga dan bagi setiap kegiatan, baik perseorangan maupun kelompok. Tanpa perencanaan atau planning, pelaksanaan suatu kegiatan akan mengalami kesulitan dan bahkan mungkin juga kegagalan (Ngalim Purwanto, 2010, h. 106). Oleh karena itu, supervisor paling tidak harus menyusun instrumen untuk pengawasan.

Ngalim Purwanto dalam Herabudin (2009, h. 239) menjelaskan bahwa perencanaan supervisi dilaksanakan dengan langkah-langkah yang disesuaikan dengan fungsi supervisi yang bersangkutan, yaitu sebagai berikut:

1. Menyusun rencana dan policy bersama.

2. Mengikutsertakan anggota-anggota kelompok (guru-guru, pegawai) dalam berbagai kegiatan.

3. Memberikan bantuan kepada anggota kelompok dalam menghadapi dan memecahkan persoalan-persoalan.

4. Membangkitkan dan memupuk semangat kelompok, atau memupuk moral yang tinggi kepada anggota kelompok.

5. Mengikutsertakan semua anggota dalam menetapkan putusanputusan.

6. Membagi-bagikan dan mendelegasikan wewenang dan tanggung jawab kepada anggota kelompok, sesuai dengan fungsi-fungsi dan kecakapan masing-masing.

7. Mempertinggi daya kreatif pada anggota kelompok. 
8. Menghilangkan rasa malu dan rasa rendah diri pada anggota kelompok sehingga mereka berani mengemukakan pendapat demi kepentingan bersama.

\section{Pelaksanaan Supervisi}

Untuk dapat menjalankan tugasnya secara efektif, supervisor pengajaran diharapkan dapat memilih teknik-teknik supervisi yang cocok dengan tujuan yang akan dicapai. Dalam Banun (2013, h. 74) Ada sejumlah teknik supervisi yang dapat dipilih dan dipraktekan supervisor, diantaranya adalah:

1. Kunjungan atau Observasi Kelas

Kunjungan kelas adalah kunjungan seorang supervisor ke kelas pada saat guru sedang mengajar, artinya supervisor menyaksikan dan mengamati guru mengajar. Para pakar supervisi menggambarkan observasi kelas dan pertemuan (conference) antara supervisor dan guru sebagai satu kegiatan yang sangat penting dan bahkan sangat terkenal dalam proses supervisi.

2. Pembicaraan Individual

Pembicaraan individual atau individual conference adalah percakapan pribadi anatar seorang supervisor dengan seorang guru. Hal itu pada umumnya merupakan rangkaian dari kegiatan kunjungan kelas, namun pembicaraan individual bisa juga dilakukan seandainya guru tertentu memerlukan bantuan supervisi (tidak harus didahului oleh kunjungan kelas). Untuk keefektifan pelaksanaan individual conference, beberapa hal berikut perlu mendapat perhatian (a) supervisor jangan memborong pembicaraan, (b) sebelum membicarakan segi-segi negatif, (kelemahan-kelemahan) guru, mulailah membicarakan segi-segi positif (kelebihan-kelebihan guru), (c) ciptakan situasi dan kondisi yang dapat membuat guru mau dan berani untuk menganalisis dan mengevaluasi hasil pekerjaannya sendiri, dan (d) supervisor memposisikan dirinya sebagai kolega bukan sebagai atasan guru.

3. Rapat Guru (Rapat Supervisi)

Rapat supervisi bisa diselenggarakan bila guru-guru memiliki masalah yang sama. Yang dimaksud dengan rapat supervisi tersebut adalah rapat yang diselenggarakan oleh supervisor untuk membahas masalah-masalah yang menyangkut usaha perbaikan dan peningkatan mutu pendidikan pada umumnya dan mutu pengajaran pada khususnya.

Glickman dalam Banun (2013, h. 77) mengemukakan ada dua pendekatan (orientasi supervisi) yang ditetapkan supervisor di dalam melakukan supervisi, yakni pendekatan direktif dan pendekatan kolaboratif.

1. Pendekatan Direktif

Pada pendekatan ini perilaku yang menonjol dari supervisor adalah "demonstrating, directing, standizing, dan reinforcing". Tanggung jawab supervisi lebih banyak berada pada supervisor, karena itu supervisor harus benar-benar mempersiapkan diri dengan cara membekali ilmu pengetahuan yang berkaitan dengan kegiatan supervisi. Supervisor menganggap bahwa dengan tanggung jawab itu ia dapat melakukan perubahan perilaku mengajar dengan memberikan pengarahan yang jelas terhadap setiap rencana kegiatan yang akan dievaluasi. Brown (1962) dalam Banun (2013, h. 77) melaporkan bahwa beberapa guru memberikan reaksi yang menyenangkan terhadap 
pendekatan ini dengan menunjukan perbaikan dalam proses pengajaran mereka. Hal ini menunjukkan bahwa ada guru, dengan cara pendekatan directive ini malah guru dapat memperbaiki cara mengajarnya.

2. Pendekatan Kolaboratif

Pada pendekatan ini perilaku supervisi yang menonjol dari supervisor adalah "presenting, problem solving, dan negotiating". Tugas supervisor dalam hal ini adalah mendengarkan dan memperhatikan secara cermat akan keprihatinan guru terhadap masalah perbaikan mengajarnya dan juga gagasangagasan guru untuk mengatasi masalahnya itu. Selanjutnya supervisor dapat meminta penjelasan kepada guru apabila ada hal-hal yang diungkapkannya kurang dipahami, kemudian ia mendorong guru untuk mengaktualisasikan inisiatif yang dipikirkannya untuk memecahkan masalah yang dihadapinya atau meningkatkan pengajarannya.

\section{Evaluasi dan Tindak Lanjut Supervisi}

Hal pertama yang perlu dilakukan dalam evaluasi supervisi pembelajaran adalah pelaksanaan supervisi pembelajaran itu sendiri. Apakah supervisi pembelajaran yang dilakukan sesuai dengan teori-teori supervisi pembelajaran atau tidak. Evaluasi terhadap supervisi pembelajaran perlu dilakukan agar diketahaui apakah supervisi pembelajaran yang dilaksanakan telah mencapai target sebagaimana yang telah ditentukan ataukah belum. Kata evaluasi merupakan peng-Indonesiaan dari kata evaluation dalam bahasa Inggris, yang lazim diartikan dengan penaksiran. Kata kerjanya adalah evaluate yang berarti menaksir dan menilai. Sedangkan orang yang menaksir atau menilai disebut dengan evaluator (Ali Imron, 2011, h. 196).

\section{Metode Penelitan}

Pendekatan yang digunakan dalam penelitian ini yakni kualitatif dengan metode deskriftif. Menurut Moleong (2014:2), pendekatan kualitatif yakni prosedur penelitian yang menghasilkan data deskriptif berupa kata-kata tertulis atau lisan dari orang-orang dan perilaku yang dapat diamati; pendekatannya diarahkan pada latar dan individu secara holistik. Penelitian ini tidak dimaksudkan untuk menguji hipotesis tetapi hanya menggambarkan secara objektif dan apa adanya mengenai Kompetensi Supervisi Kepala Madrasah di MTs Nurul Iman Cibaduyut-Bandung. Teknik pengumpulan data dilakukan dengan teknik wawancara, observasi, dan studi dokumentasi. Teknik wawancara dengan menggunakan model wawancara baku terbuka; yaitu guru sebagai key informant mengetahui bahwa mereka sedang diwawancarai dan mengetahui maksud dan tujuan wawancara. Metode observasi yang digunakan peneliti adalah observasi berperan artinya peneliti ikut serta dalam pelaksanaan kegiatan yang dilakukan di MTs Nurul Iman Cibaduyut-Bandung. Teknik studi dokumentasi bisa berbentuk tulisan, gambar, atau karya-karya monumental dari seseorang, dokumen yang dihimpun dipilih yang sesuai dengan tujuan dan fokus masalah. Sedangkan dalam menganalisis data yang digunakan adalah analisis dengan penafsiran deskriftif semata-mata. 


\section{HASIL DAN PEMBAHASAN}

Berikut ini akan dibahas secara rinci terkait Kompetensi Supervisi Kepala Madrasah di MTs Nurul Iman Cibaduyut-Bandung, yang menjadi hasil dari Kompetensi Supervisi Kepala Madrasah. Pertama, perencanaan program supervisi. Kedua, pelaksanaan program supervisi. Ketiga, evaluasi dan tindak lanjut hasil supervisi. Uraiannya rincinya yakni:

\section{Perencanaan Program Supervisi}

1) Tujuan: acuan bagi pelaksanaan kegiatan supervisi di lingkungan MTs Nurul Iman, mengetahui kinerja guru, meningkatkan profesionalisme guru dalam melaksanakan tugas pokok dan fungsinya sebagai pendidik, dan mengevaluasi program-program yang sudah direncanakan sejauh mana ketercapaiannya, agar perjalanan pendidikannya seiring berjalan lebih baik, dan meningkatkan kualitas proses pembelajaran pada setiap mata pelajaran yang bermuara pada peningkatan kualitas tamatan.

2) Kebijakan, dengan melengkapi perangkat administrasi guru dan proses belajar mengajar yang sesuai dengan instrumen yang telah ditentukan.

3) Strategi: supervisi MTs Nurul Iman mempunyai instrumen tertentu yang telah disiapkan kemudian dari instrumen tersebut dinilai dan dipantau, mulai dari kerapihan guru, cara mengajar, perhatian siswa kepada penyampaian guru, dan metode pengajaran yang dilakukan guru, mengecek kelengkapan administrasi guru, dan ketika guru mengajar harus disesuaikan dengan yang ditargetkan dan sesuai dengan RPP yang dibuat. Instrumen tersebut diantaranya terdapat: Supervisi kunjungan kelas yang terdiri dari:

a) persiapan: silabus, program tahunan \& program semesteran, RPP, rencana pengajaran untuk materi yang disajikan, buku nilai untuk nilai harian, tugas, ulangan umum. Kegiatan pembelajaran diantaranya terdapat

b) pendahuluan: penampilan guru, apersepsi \& motivasi, menuliskan/ memberitahukan PB/SPB dan TPK.

c) Kegiatan pokok: penguasaan materi, penyajian sesuai dengan urutan materi, metode/pendekatan sesuai materi, penggunaan alat bantu/peraga, alat bantu mengajar, keterlibatan siswa, bimbingan kepada siswa, teknik bertanya, penggunaan bahasa Indonesia yang baik dan benar, pengembangan keterampilan siswa: pengguna alat peraga, pemecahan masalah, pemanfaatan lingkungan, pengungkapan, pidato dan sebagainya, menghubungkan materi pelajaran dengan budi pekerti, kehidupan sehari-hari, teknologi, lingkungan dan

d) penutup: membuat rangkuman, memberi tugas/PR, pelaksanaan sesuai dengan waktu, mengakhiri pelajaran dengan baik. Rentang nilai yang digunakan dari 2-6, dengan skala ketercapaian; 91-100=A; 70-90=B; 55$74=\mathrm{C} ;<55=\mathrm{K}$.

4) Program yang direncanakan dilaksanakan pada semester ganjil \& genap, dan rapat rutin bulanan. Program semester ganjil dan genap melalui kunjungan ke kelas, kemudian ada tindak lanjut dari hasil kunjungan kelas tersebut, dan rapat rutin bulanan sekaligus pengajian dan pembagian honor yang dijadwalkan pada minggu pertama.

Program supervisi MTs Nurul Iman tidak terlepas dari tujuan, kebijakan, dan strategi yang direncanakan untuk menunjang keberhasilan supervisi. 
Menurut Muriel Crosby dalam bukunya Coordinating a Supervisory Program, in Suervision Emerging Profession, tujuan supervisi pendidikan adalah menciptakan kondisi yang memungkinkan pemberi bantuan kepada guru agar mampu membina dirinya sehingga terampil dalam menjalankan usaha-usaha yang menunjang proses belajar mengajar. Sama halnya dengan tujuan supervisi di MTs Nurul Iman yaitu mengetahui kinerja guru, meningkatkan profesionalisme guru dalam melaksanakan tugas pokok dan fungsinya sebagai pendidik, dan mengevaluasi program-program yang sudah direncanakan sejauh mana ketercapaiannya.

Tujuan program supervisi dapat tercapai dengan adanya kebijakan dan strategi yang direncanakan oleh pihak madrasah. Kebijakan dalam menunjang tujuan supervisi yaitu silabus, RPP, prota, promes, hasil kegiatan UTS dan UAS (surat tugas, soal ulangan \& daftar nilai), agenda guru, buku tamu, buku kasus dan notulen rapat, buku leger dan catatan home visit (bagi wali kelas). MTs Nurul Iman melakukan srategi untuk mencapai tujuan supervisi dengan cara melakukan supervisi kunjungan kelas. Kebijakan dan strategi ini dilakukan untuk mencapai tujuan supervisi di MTs Nurul Iman.

\section{Pelaksanaan Program Supervisi}

Pelaksanaan supervisi dilakukan oleh semua guru, dan Kepala Madrasah sebagai supervisor. Langkah persiapan pelaksanaannya yaitu dengan menentukan jadwal pelaksanaan, menyebarkan surat pemberitahuan ke semua guru dan guru harus menyiapkan perangkat administrasi dan bahan ajar, media pembelajaran yang berkaitan dengan materi pada saat pelaksanaan pembelajaran. Kegiatan-kegiatan supervise meliputi supervisi kelengkapan perangkat administrasi guru/wali kelas dan supervisi kegiatan pembelajaran.

Teknik supervisi yang diterapkan yaitu melalui: a) Kunjungan atau observasi kelas yang terjadwal diadakan 1 kali selama 2 minggu, dan yang tidak terjadwal disesuaikan dengan kebutuhan Kepala Madrasah. b) Workshop dengan mendatangkan narasumber yang kompeten dalam bidangnya dan memberikan bimbingan. c) Pembicaraan individual antara guru dan Kepala Madrasah untuk memperbaiki kekurangan pada diri individu guru. d) Rapat guru diadakan sebulan sekali diawal bulan minggu pertama sekaligus pengajian dan pembagian honor. Pelaporan supervisi di MTs Nurul Iman dilakukan oleh Kepala Madrasah kepada Pengawas Madrasah dalam kunjungannya, khususnya dalam kegiatan akreditasi sekolah.

Menurut Ngalim Purwanto menjelaskan bahwa pelaksanaan supervisi dilaksanakan dengan langkah-langkah yang disesuaikan dengan fungsi supervisi yang bersangkutan. Sama halnya dengan pelaksanaan supervisi di MTs Nurul Iman yaitu adanya penentuan jadwal pelaksanaan, menyebarkan surat pemberitahuan ke semua guru dan guru harus menyiapkan perangkat administrasi dan bahan ajar, media pembelajaran yang berkaitan dengan materi pada saat pelaksanaan pembelajaran.

Kegiatan supervisi MTs Nurul Iman minimal dilakukan satu tahun sekali meskipun idealnya supervisi itu dilaksanakan satu tahun dua kali pada semester genap dan semester ganjil. Teknik supervisi menurut Sri Banun yaitu dengan kunjungan atau observasi kelas, pembicaraan individual, dan rapat guru, teori tersebut sesuai dengan penelitian di MTs Nurul Iman teknik supervisi 
yang digunakan adalah kunjungan atau observasi kelas, pembicaraan individual, rapat guru, dan workshop sebagai tambahan untuk menunjang kemampuan guru dalam meningkatkan kompetensi guru.

Pelaporan hasil supervisi biasanya diketahui oleh Pengawas Madrasah dalam kunjungannya, khususnya dalam kegiatan akreditasi sekolah. Pelaporan dilakukan oleh Kepala Madrasah kepada Pengawas Madrasah, ketika ada keluhan atau hal-hal yang tidak bisa dipecahkan oleh Kepala Madrasah yang nanti akan dibimbing dan diarahkan oleh pengawas, minimal dilakukan satu tahun satu kali dan bisa lebih dari itu pada saat beliau berkunjung ke sekolah.

Hasil dari supervisi di tandatangani oleh guru yang bersangkutan dan oleh Kepala Madrasah bahwa telah melaksanakan supervisi, kemudian dikumpulkan dalam satu bundel dan direkap oleh Kepala Madrasah untuk nanti dilaporkan dalam akreditasi. Laporan supervisi di MTs Nurul Iman terdiri dari empat bab, yaitu bab I Pendahuluan yang terdiri dari Latar Belakang Masalah, Landasan Hukum, Tujuan, dan Ruang Lingkup. Bab II berisi Analisis Hasil Supervisi Tahun lalu, bab III Rencana Pelaksanaan Supervisi terdiri dari Rencana Supervisi Akademis, Rencana Supervisi Internal Manajerial, Jadwal Kegiatan Supervisi Akademis, Jadwal Kegiatan Supervisi Internal Manajerial. Bab IV berisi Penutup dan terdapat Lampiran Instrumen Supervisi.

\section{Evaluasi dan Tindak Lanjut Supervisi}

Evaluasi supervisi di MTs Nurul Iman dilaksanakan secara tidak langsung pada rapat rutin bulanan pada minggu pertama sekaligus evaluasi kinerja guru setelah pelaksanaan supervisi selesai dilaksanakan, dikumpulkan oleh Kepala Madrasah bahwa ada beberapa guru dalam pelaksanaan pembelajaran seperti apa, dengan mendiskusikan kekurangan-kekurangan pada saat kunjungan supervisi baik yang terjadwal dan tidak terjadwal.

Diungkap pula saran, keinginan dan ide-ide guru tentang upaya lainnya yang dapat dilakukan dalam memperbaiki proses pembelajaran. Menurut Kepala Madrasah, dalam forum rapat sekaligus pengajian ini sangat menolong untuk konsultasi, tanya jawab, dan mendiskusikan langkah-langkah supervisi selanjutnya yang akan datang. Adapun lembar evaluasi RPP rinciannya dilampirkan.

Tindak lanjut supervisi di MTs Nurul Iman dilakukan dengan dua cara yaitu: 1) Perorangan, jika masalah/kekurangannya hanya pada beberapa guru yaitu dengan memberitahukan kekurangannya dimana dan supaya diperbaiki melalui pembicaraan individual, dan 2) Rapat guru, jika masalah setiap guru rata-rata sama, secara umum ditindak lanjutnya melalui diskusi

Dari hasil supervisi, catatan dari Kepala Madrasah dijadikan bahan masukan oleh guru yang masih kurang agar diperbaiki dan yang sudah bagus supaya dipertahankan dan ditingkatkan. Dari hasil supervisi juga didiskusikan dan berusaha bersama-sama untuk mencari jalan keluar dalam upaya perbaikan dan peningkatan kualitas pembelajaran.

Presentase jumlah guru yang telah disupervisi dan dimonitor oleh Kepala Sekolah/Madrasah sebagai berikut: 
Tabel 1

Guru Yang Telah Disupervisi Dan Dimonitor Oleh Kepala Madarasah

\begin{tabular}{|c|c|c|c|c|}
\hline No & Mata Pelajaran & $\begin{array}{l}\text { Jumlah } \\
\text { Guru }\end{array}$ & Jumlah & $\%$ \\
\hline 1 & Qur'an Hadits & 3 & 3 & $100 \%$ \\
\hline 2 & Akidah Akhlak & 3 & 3 & $100 \%$ \\
\hline 3 & Fiqih & 3 & 3 & $100 \%$ \\
\hline 4 & SKI & 2 & 2 & $100 \%$ \\
\hline 5 & PKN & 2 & 2 & $100 \%$ \\
\hline 6 & $\begin{array}{l}\text { Bahasa } \\
\text { Indonesia }\end{array}$ & 3 & 3 & $100 \%$ \\
\hline 7 & Bahasa Arab & 3 & 3 & $100 \%$ \\
\hline 8 & Bahasa Inggris & 3 & 3 & $100 \%$ \\
\hline 9 & Matematika & 3 & 3 & $100 \%$ \\
\hline 10 & IPA & 4 & 4 & $100 \%$ \\
\hline 11 & IPS & 3 & 3 & $100 \%$ \\
\hline 12 & Seni Budaya & 2 & 2 & $100 \%$ \\
\hline 13 & Penjas & 2 & 2 & $100 \%$ \\
\hline 14 & TIK & 2 & 2 & $100 \%$ \\
\hline 15 & Bahasa Sunda & 2 & 2 & $100 \%$ \\
\hline 16 & KTA & 5 & 5 & $100 \%$ \\
\hline 17 & PLH & 5 & 5 & $100 \%$ \\
\hline 18 & BTQ & 21 & 21 & $100 \%$ \\
\hline 19 & Hadits Arbain & 4 & 4 & $100 \%$ \\
\hline 20 & Aqoiduddiniyyah & 3 & 3 & $100 \%$ \\
\hline 21 & Safinah & 6 & 6 & $100 \%$ \\
\hline 22 & Kalighrafi & 4 & 4 & $100 \%$ \\
\hline 23 & Tahfidz & 5 & 5 & $100 \%$ \\
\hline
\end{tabular}

Kepala Madrasah MTs Nurul Iman sudah cukup bagus, tidak mempersulit. Setiap tahunnya sudah ada program supervisi. Semua hal mendukung dalam kegiatan supervisi, fasilitas yang disediakan sekolah tersedia, seperti fasilitas membuat perangkat administrasi dan fasilitas selama pembelajaran di kelas. Dan guru yang menjadi sasaran supervisi sudah terbiasa dengan adanya kegiatan supervisi, bahkan sebagian guru merasa ingin dan senang jika supervisi dilakukan dalam meningkatkan kualitas kerja mereka.

Kegiatan dan tugas Kepala Madrasah yang harus membatalkan kegiatan supervisi karena adanya kegiatan di luar, karena Kepala Madrasah selain memiliki peran fungsional melaksanakan supervisi akademik, masih mempunyai tanggung jawab lain, seperti pertemuan dengan pihak lain untuk kepentingan sekolah, mengelola hubungan sekolah/madrasah dan masyarakat dalam rangka pencarian ide, sumber belajar, dan pembiayaan sekolah/madrasah, pengelolaan pengembangan kurikulum agar sesuai dengan arah dan tujuan pendidikan nasional, dan sebagainya. Sehingga jadwal 
supervisi akademik yang telah dibuat sebelumnya bisa berubah-ubah menyesuaikann waktu kosong Kepala Madrasah.

Faktor ketidak disiplinan Guru, ketika kelengkapan guru tidak lengkap, guru tersebut tidak siap dan meminta untuk diundur dan ketika diundur akan menambah kerja dari Kepala Madrasah. Tetapi faktor ketidak disiplinan tersebut tidak terjadi pada semua guru, melainkan hanya pada beberapa guru.

Cara mengatasi penghambat tersebut salah satunya dengan memberi ketegasan dan kesepakatan bersama ketika rapat agar guru yang akan disupervisi meluangkan waktunya untuk melengkapi perangkat administrasi sehingga nanti ketika disupervisi Kepala Madarasah bisa mengontrol sesuai dengan jadwal yang telah direncanakan.

\section{SIMPULAN}

Berdasarkan analisis hasil penelitian mengenai Kompetensi Supervisi Kepala Madrasah di MTs Nurul Iman Cibaduyut-Bandung, diperoleh simpulan sebagai berikut: 1) Rancangan dari perencanaan supervisi yaitu tujuan, kebijakan, strategi, dan program yang matang untuk melaksanakan suatu kegiatan program supervisi. 2) Pelaksanaan supervisi dilakukan oleh semua guru, dan Kepala Madrasah sebagai supervisor. Langkah persiapan pelaksanaannya yaitu dengan menentukan jadwal pelaksanaan, menyebarkan surat pemberitahuan ke semua guru dan guru harus menyiapkan perangkat administrasi dan bahan ajar, media pembelajaran yang berkaitan dengan materi pada saat pelaksanaan pembelajaran. Kegiatan-kegiatan supervisi meliputi supervisi kelengkapan perangkat administrasi guru/wali kelas dan supervisi kegiatan pembelajaran. Teknik supervisi yang diterapkan yaitu melalui: a) Kunjungan atau observasi kelas, b) Workshop, c) Pembicaraan individual, d) Rapat guru. Pelaporan supervisi di MTs Nurul Iman dilakukan oleh Kepala Madrasah kepada Pengawas Madrasah dalam kunjungannya, khususnya dalam kegiatan akreditasi sekolah. 3) Evaluasi supervisi di MTs Nurul Iman dilaksanakan secara tidak langsung pada rapat rutin bulanan, dengan mendiskusikan kekurangan-kekurangan pada saat kunjungan supervisi baik yang terjadwal dan tidak terjadwal. Diungkap pula saran, keinginan dan ide-ide guru tentang upaya lainnya yang dapat dilakukan dalam memperbaiki proses pembelajaran. Tindak lanjut supervisi di MTs Nurul Iman dilakukan dengan dua cara yaitu perorangan dan rapat guru.

\section{REFERENSI}

Banun, S. (2013). Supervisi Pendidikan Meningkatkan Kualitas Profesionalisme Guru. Bandung: Alfabeta.

Herabudin. (2009). Administrasi dan Supervisi Pendidikan. Bandung: Pustaka Setia.

Imron, A. (2011). Supervisi Pembelajaran Tingkat Satuan Pendidikan. Jakarta: Bumi Aksara.

Moleong, L. (2011). Metodologi Penelitian Kualitatif. Bandung: Remaja Rosdakarya.

Permendiknas RI Nomor 13 Tahun 2007, tentang Kualifikasi dan Kompetensi Kepala Sekolah/ Madrasah. 
Kompetensi Supervisi ...

Purwanto, N. (2010). Administrasi dan Supervisi Pendidikan. Bandung: Remaja Rosdakarya.

Soetopo, H. \& Wasty S. (1982). Kepemimpinan dan Supervisi Pendidikan. Jakarta: Bina Aksara. 
Irfani Nabila 